\title{
Fatty Acid Analysis of Oocytes, Oviductal and Uterine Fluids of Rabbit
}

\author{
MAM Yahia KHANDOKER, Hirotada TSUJII \\ and Den'ei KARASAWA \\ Department of Agricultural Biotechnology, Shinshu University, \\ Minami-minowa-mura, Nagano-ken 399-45
}

(Received December 21, 1995)

\begin{abstract}
The fatty acid compositions of oocytes, oviductal and uterine fluids of rabbit were analyzed by gas chromatography and were compared with those of blood serum and body fat. Myristic (C 14:0), palmitic (C 16:0), palmitoleic (C 16:1), stearic (C 18:0), oleic (C 18:1), linoleic (C $18: 2)$ and linolenic ( $\mathrm{C} 18: 3$ ) acids were identified as the common fatty acid constituents in the objects. The fatty acid constituents of reproductive tracts fluids seemed to be quite similar to those of blood serum and body fat. In oocytes and different reproductive fluids, oleic acid composition was the highest (26.59 to $32.79 \%$ ), followed by palmitic (21.83 to $25.8 \%$ ), and linoleic (18.33 to $23.55 \%$ ) acid. Myristic, palmitoleic, stearic and linolenic acid compositions were always low in oviductal (2.12 to $7.91 \%$ ) and uterine (2.05 to $10.48 \%$ ) fluids. On the other hand, myristic and stearic acíd were moderate ( 16.66 and $14.17 \%$, respectively) but palmitoleic and linolenic acid were not detected in oocytes. Palmitic, stearic, oleic and linoleic acids comprised more than $80 \%(82.24$ to $86.43 \%$ ) of the total fatty acid fraction in all samples analyzed.
\end{abstract}

Anim. Sci. Technol. (Jpn.) 67 (6) : 549-553, 1996

Key words : Fatty acid, Oocyte, Oviductal fluid, Uterine fluid, Rabbit

Our previous work indicated that reproductive fluids of pig and cow contained several saturated (myristic, palmitic and stearic) and unsaturated (palmitoleic, oleic and inoleic) fatty acids. Quantitatively, the most abundant fatty acids were palmitic, stearic, oleic and linoleic acids. The fatty acid constituents and compositions of different reproductive fluids were more or less same and they seemed to be quite similar to those of body fat of the same animal ${ }^{8)}$. We observed that BSA binding fatty acids had considerable effect on mouse and rat embryo development ${ }^{7)}$. Moreo- ver, it was reported that exogenously supplied fatty acids are beneficial for growth and continued development of rabbit embryo ${ }^{4,5)}$. The culture media, usually devised based on the composition of reproductive fluids ${ }^{15,19}$. There is no report about fatty acid composition of oocytes, oviductal and uterine fluids of rabbit to date. In this situation, the analysis of fatty acid composition of reproductive fluids of rabbit bears importance, because they provide environment to the oocytes and preimplantation embryo in vivo. So, the present study was undertaken to determine the fatty acid compo-

ウサギ卵母細胞，卵管抢よび子宮液中の脂肪酸の分析：MAM Yahia Khandoker ·辻井弘忠・唐沢伝英（信州大 学農学部, 長野県南箕輸村 399-45) 


\section{KHANDOKER, TSUJII and KARASAWA}

sition of oocytes, oviductal and uterine fluids of rabbit and for comparison we also analyzed blood serum and body fat of the same animal.

\section{Materials and Methods}

Sample collection: Reproductive ducts were collected from superovulated New Zealand White does which were maintained singly in metal cage. Superovulation was performed by marginal ear vein injection of $50 \mathrm{IU}$ pregnant mare serum gonadotrophin (PMSG) followed $48 \mathrm{~h}$ later by $50 \mathrm{IU}$ human chorionic gonadotrophin (hCG). Reproductive ducts were collected from 30 does, $8-10 \mathrm{~h}$ after hCG injection. Ovary, oviduct and uterus were separated. They were dissected free of other tissues, rinsed thoroughly in $0.9 \%(\mathrm{w} / \mathrm{v}) \mathrm{NaCl}$, blotted dry on paper towel. Oocytes were collected by scratching of ovary in phosphate buffer saline (PBS) solution and cumulus cells were removed by using hyaluronidase $(1 \mathrm{mg}$ / $\mathrm{m} l$ PBS). The oocytes were then washed three times in PBS and 240 cumulus cell free oocytes were collected. To collect the oviductal and uterine fluids they were flushed with chloroform-methanol mixture $(2: 1)$ and precautions were taken to avoid contamination. The oviductal and uterine fluids were then filtered, using $75 \mu \mathrm{m}$ filter paper (Toyo Roshi Kaisha, Tokyo, Japan) and most of the solvent were evaporated. Body fat and blood serum (from blood) were also collected to analyze fatty acid. All the samples were stored at $-40^{\circ} \mathrm{C}$ until further preparation for analysis.

Sample preparation: All the samples were extracted separately with diethyl ether, the ether layers were collected and dried with anhydrous $\mathrm{Na}_{2} \mathrm{SO}_{4}$ overnight at $4^{\circ} \mathrm{C}$. Total lipid extracts were evaporated to dryness using evaporator and the weight was measured. In order to identify the unknown acids, the methylation was performed according to the method described by Stoffel et al. ${ }^{18}$. Briefly, 1 $\mathrm{m} l$ benzene and $1 \mathrm{~m} l 0.5 \mathrm{~N}$ sodium methoxide (GL Science, Japan) were added for each 10-30 mg extract in a centrifuge tube, a conical bottom with stopper. The tube was heated to $80^{\circ} \mathrm{C}$ and maintained for $15-20 \mathrm{~min}$ in a water bath for complete methylation. It was then allowed to cool in room temperature, and $3 \mathrm{~m} l$ each of diethyl ether and distilled water were added and mixed well. The lower aqueous layer was removed and the top solvent layer washed more than twice with $2-3 \mathrm{ml}$ distilled water and dried overnight by adding anhydrous $\mathrm{Na}_{2} \mathrm{SO}_{4}$ at $4^{\circ} \mathrm{C}$. Final evaporation was performed and stored at $-40^{\circ} \mathrm{C}$ until analysis.

Gas Chromatography : The methyl ester of fatty acids were dissolved in 10-20 $\mu l$ ethyl acetate. Composition of fatty acid methyl esters were determined by gas chromatograph (Shimadzu GC-6 A, Japan) with a flame ionization detector. The chromatograms were recorded on a thermal-pen recorder (Shimadzu, C-R $1 \mathrm{~A}$, Chromatopac). A diethylene glycol succinate (DEGS) column was used for analysis $: 2 \mathrm{~m}$ long and $3 \mathrm{~mm}$ i.d. packed with Chromosorb W 60-80 mesh. The column temperature was, initial $120^{\circ} \mathrm{C}$ and final $190^{\circ} \mathrm{C}$; carrier gas was helium $(30 \mathrm{ml} / \mathrm{min})$ and the maximum sample size was $1 \mu l$. The sequence of methylated fatty acid peaks were identified by comparison with authentic standards (Lipid standard, Sigma Chemical Co., USA) and the results were reported as area percent. All samples analyzed were properly separated within 1 hour.

\section{Results and Discussion}

The fatty acid contents and compositions are shown in Table 1. Myristic (C 14:0), palmitic (C 16:0), palmitoleic (C 16:1), stearic (C 18:0), oleic (C 18:1), linoleic (C 18:2) and linolenic (C $18: 3)$ acids were the common fatty acid constituents. The fatty acid composition of oocytes and different reproductive fluids seemed to be quite similar to that of blood serum and body fat. In oocytes and different reproductive fluids, oleic acid constituents was the highest $(26.59$ to $32.79 \%)$, followed by pal- 
Fatty Acids of Rabbit Reproductive Sample

Table 1. Fatty acid constituents and composition (\%) in rabbit sample

\begin{tabular}{|c|c|c|c|c|c|}
\hline \multirow{2}{*}{$\underset{C}{\text { Fatty acid }}$} & \multicolumn{5}{|c|}{ Sample (ether extract) } \\
\hline & $\begin{array}{l}\text { Body fat } \\
(80.6)^{a}\end{array}$ & $\begin{array}{l}\text { Blood serum } \\
\quad(61.8)\end{array}$ & $\begin{array}{c}\text { Oocytes } \\
(5.1)\end{array}$ & $\begin{array}{c}\text { Oviductal fluid } \\
(44.8)\end{array}$ & $\begin{array}{l}\text { Uterine fluid } \\
\quad(60.2)\end{array}$ \\
\hline $14: 0$ & 2.15 & 3,06 & 16.66 & 2. 12 & 2.05 \\
\hline $16: 0$ & 25.56 & 24.23 & 22.08 & 25.81 & 21.83 \\
\hline $16: 1$ & 3.67 & 3.18 & ND & 7.91 & 6.70 \\
\hline $18: 0$ & 5. 95 & 6.25 & 14.17 & 2.01 & 10.48 \\
\hline $18: 1$ & 20.10 & 21.52 & 28.75 & 26.59 & 32.79 \\
\hline $18: 2$ & 30.63 & 30.41 & 18.33 & 23.55 & 21.33 \\
\hline $18: 3$ & 11.94 & 11.34 & $\mathrm{ND}$ & 6.99 & 4.82 \\
\hline
\end{tabular}

${ }^{a}$ Average amount of ether extract (mg) per pool are shown in parentheses. ND, Not detected.

mitic (21.83 to $25.81 \%$ ), and linoleic (18.33 to $23.55 \%)$ acids. Myristic, palmitoleic, stearic and linolenic acid composition were determined to lower in oviductal (2.12 to $7.91 \%$ ) and uterine (2.05 to $10.48 \%$ ) fluids. On the other hand, myristic and stearic acids were moderate (16.66 and $14.17 \%$ respectively) but palmitoleic and linolenic acid were not detected in oocytes. Linoleic and linolenic acids were the two polyunsaturated fatty acid of oviductal and uterine fluids.

These results were supported by our previous work and we obtained the same types of fatty acids by analyzing different reproductive fluids of pig and $\mathrm{cow}^{8}$. Oleic, palmitic and linoleic acids were observed in descending order of abundance. This result was also supported by other researchers, and the same trend of fatty acid composition was observed by analyzing pig depot fats, serum and follicular fluid ${ }^{6,8,20)}$. The higher composition of oleic and palmitic acids found in all reproductive fluids may serve as a storage pool of metabolic precursors, as these fatty acids are required as substrates for fatty acid elongation and desaturation in embryo development $t^{3)}$. On the other hand, the combination of palmitic and oleic acid was more effective in mouse embryo development ${ }^{14)}$. The common constituents of fatty acid in different reproductive fluids indicated that the origin of those fatty acids is same, the blood ${ }^{1,12)}$. Similarly, the different composition of those fatty acids also indicated that the secretion, as well as transudation process may be different ${ }^{2,9,133}$.

We found linoleic and linolenic acid as the two poly-unsaturated fatty acids in oviductal and uterine fluids. This result differs from our previous observation ${ }^{8)}$, and might be due to species difference. Nutritionally, linoleic, linolenic and arachidonic acids are usually referred to as essential fatty acids, although neither linolenic nor arachidonic acid is truly essential, since linoleic acid is able to transform itself to other two fatty acids when required ${ }^{10)}$. Therefore, the high concentration of linoleic acid found in oviductal fluid ( $23.55 \%$ ) and uterine fluid (21.33\%) might fulfill the essentiality of these three fatty acids. The high concentration of linoleic acid in rabbit reproductive fluids may be indicative of the capacity of those samples to synthesize prostaglandin, as arachidonic acid, which is derived from linoleic acid, and is the primary substrate for cyclooxygenase and lipoxygenase ${ }^{16)}$. The lower amount of myristic and palmitoleic acids in all samples analyzed, except myristic acid in oocytes, was also supported by Yao et al. ${ }^{20)}$. They found only 1.0 and $2.8 \%$ myristic and palmitoleic acid, respectively, in pig follicular fluid. The lower amount of myristic, palmitoleic, stearic and linolenic acids in oviductal 
and uterine fluids may imply the less importance of those fatty acids for the maintenance of congenial environment in the oviduct and uterus. Palmitic, stearic, oleic and linoleic acids comprised more than $80 \%$ (82.24 to $86.43 \%$ ) of the total fatty acid in the different samples analyzed. Spector ${ }^{17}$, stated that those type of fatty acids comprise approximately $80 \%$ of the total fatty acids fraction in human and most animal sera.

$\mathrm{Kane}^{4)}$ reported that myristic, palmitic, stearic, oleic and to a lesser extent, the short chain acids, i.e, acetic and propionic, can support growth of 1-cell rabbit ova to viable morulae in a simple salt solution containing defatted BSA. The information in the literature indicated that BSA contain $0.17 \mathrm{~mol}$ fatty acids ${ }^{1}$. On the other hand, the chromatographic results of BSA indicate that it contains several saturated and unsaturated fatty acids ${ }^{7,11}$. So, it can be assumed that BSA in culture media and reproductive tract fluid may be supplies different fatty acids in vitro and in vivo, respectively, in the case of rabbit embryo development.

\section{Acknowledgements}

We thank Kitayama Labes Co. Ltd. for providing the rabbit sample; Masahiro Nishioka for assisting sample collection and Fumihide Inoue for preparation of gas chromatograph equipment and helpful discussion.

\section{References}

1) Bishop DW. Active secretion in the rabbit oviduct. Am. J. Physiol., 187 : 347-352. 1956.

2) Edwards RG. Follicular fluid. J. Reprod. Fert., 37: 189-219. 1974.

3) Jeffcoat $R$. The biosynthesis of unsaturated fatty acids and its control in mammalian liver. Essays Biochem., 15 : 1-36. 1979.

4) Kane MT. Fatty acids as energy sources for culture of one-cell rabbit ova to viable morulae. Biol. Reprod., 20 : 323-332. 1979.

5) Kane MT, Headon DR. The role of commercial bovine serum albumin preparations in the culture of one-cell rabbit embryos to blastocysts. J. Reprod. Fertil., 60 : 469-475. 1980.
6) Katsuma M, Hirose H, Kaji Y, Saitoh M. Influence of high ambient temperature and dietary fat supplementation on fatty acid composition of depot fats in finishing pigs. Anim. Sci. Technol. (Jpn.), 66 : 225-232. 1995.

7) Khandoker MAMY, Nishioka M, Tsujii $H$. Effect of BSA binding fatty acids on mouse and rat embryo development. J. Mamm. Ova Res. (Jpn.), 12 : 113-118. 1995.

8) Khandoker MAMY, Tsujii H, Karasawa D. Fatty acid analysis of follicular, oviduct and uterine fluids of pig and cow by gas chromatography. J. Chrom. B. (Submitted).

9) Leese HJ. The formation and function of ovi. duct fluid. J. Reprod. Fert., 82 : 843-856. 1988.

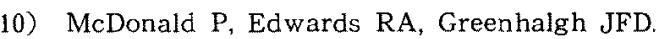
Lipids. In : Animal Nutrition. 2nd ed. 25-41 Oliver \& Boyd. Edinburgh. 1973.

11) Menezo Y, Renard JP, Delobel B, Pageaux JF. Kinetic study of fatty acid composition on Day 7 to Day 14 cow embryos. Biol. Reprod., 26 787-790. 1982.

12) Oliphant G, Reynolds $A B$, Smith PF, Ross $P R$ Marta JS. Immunocy tochemical localization and determination of hormone-induced synthesis of the sulfated oviductal glycoproteins. Biol. Reprod., 31 : 165-174. 1984.

13) Perkins JL, Goode WA, Wilder JR, Henson DB. Collection of secretions from the oviduct and uterus of the ewe. J. Anim. Sci., 24 : 383-387. 1965.

14) Quinn P. Whittingham DG. Effect of fatty acids on fertilization and development of mouse embryos in vitro. J. Androl., $3: 440-444$. 1982.

15) Quinn P, Kerin JF, Warnes GM. Improved pregnancy rate in human in vitro fertilization with the use of a medium based on the composition of human tubal fluid. Fertil. Steril., 44 : 493-498. 1985.

16) Samuelsson B. From studies of biochemical mechanism to novel biological mediators: prostaglandin endoperoxides, thromboxanes and leukotrienes. Biosci. Rep., 3 : 791-813. 1983.

17) Spector AA. Metabolism of free fatty acids. Prog. Biochem. Pharmacol., 6 : 130-176. 1971.

18) Stoffel W, Chu F, Ahrens EH. Analysis of long chain fatty acids by Gas-liquid Chromatography. Anal. Chem., 31. $2: 307-308.1959$.

19) Tervit HR, Whittingham DG, Rowson LEA. Successful culture in vitro of sheep and cattle ova. J. Reprod. Fertil., 30 : 493-497. 1972.

20) Yao JK, Ryan RJ, Dyck PJ. The porcine ovari- 
Fatty Acids of Rabbit Reproductive Sample

an follicle. VI. Composition of Fatty Acid. Composition of Serum and Follicular Fluid at
Different Developmental Stages. Biol. Reprod. 22: 141-147. 1980. 